\title{
Die middel-adolessent se wiskundeprestasie: Die rol van emosionele intelligensie en studie-oriëntasie
}

\author{
Author: \\ Petro Erasmus ${ }^{1}$ \\ Affiliation: \\ ${ }^{1}$ Departement of Psychology, \\ North-West University, \\ South Africa \\ Correspondence to: \\ Petro Erasmus \\ Email: \\ petro.erasmus@nwu.ac.za \\ Postal address: \\ Private Bag X2046, \\ Mmabatho 2745, \\ South Africa \\ Dates: \\ Received: 31 May 2013 \\ Accepted: 22 Oct. 2013 \\ Published: 19 Dec. 2013 \\ How to cite this article: \\ Erasmus, P., 2013, 'Die \\ middel-adolessent se \\ wiskundeprestasie: Die rol \\ van emosionele intelligensie \\ en studie-oriëntasie', \\ Suid-Afrikaanse Tydskrif \\ vir Natuurwetenskap en \\ Tegnologie 32(1), Art. \#418, \\ 10 pages. http://dx.doi. \\ org/10.4102/satnt.v32i1.418 \\ Copyright: \\ (C) 2013. The Authors. \\ Licensee: AOSIS \\ OpenJournals. This work \\ is licensed under the \\ Creative Commons \\ Attribution License.
}

Read online:
Hierdie artikel het ten doel om oorsigtelik 'n insae te bied in die bevindinge van 'n studie (kwantitatief-kwalitatief) wat veral gefokus het op die mate waartoe 'n kombinasie van komponente van emosionele intelligensie en dimensies van studie-oriëntasie middel-adolessente se wiskundeprestasie voorspel, asook hoe die prestasies van verskillende geslag- en graadgroepe (in hierdie studie verteenwoordig) in dié opsig vergelyk. Altesaam 435 leerlinge in graad 9 en graad 11 aan die drie Engelsmedium-hoërskole in die Mafikeng-area het aan die studie deelgeneem. Die kwantitatiewe komponent van die studie het bestaan uit die implementering van twee gestandaardiseerde vraelyste. Leerders is gevra om 'n EI-vraelys, naamlik die Bar-On EQ-i:YV ${ }^{\mathrm{TM}}$ en die studie-oriëntasievraelys in wiskunde (SOW) te voltooi, terwyl die kwalitatiewe tegniek wat in hierdie studie geïmplementeer is, fokusgroeponderhoude was. Die resultate dui daarop dat 'n kombinasie van die komponente van emosionele intelligensie en die dimensies van studie-oriëntasie as moontlike voorspellers van die middel-adolessent se wiskundeprestasie beskou kan word. Die volgende emosionele intelligensie (EI)-komponente het as voorspellers van wiskundeprestasie na vore getree: algemene gemoedstoestand, aanpasbaarheid en intrapersoonlike gedrag. Die volgende studie-oriëntering in wiskunde (SOW)-dimensies was voorspellers van wiskundeprestasie: probleemoplossing, studiegewoontes, inligtingverwerking en wiskundeangs. Temas wat uit die kwalitatiewe aspek van hierdie studie na vore getree het as moontlik bydraend tot leerders se ontoereikende wiskundeprestasie in Suid-Afrika, verwys spesifiek na uitdagings op makrovlak, naamlik in die maatskaplik ekonomiese kontekste; op mesovlak, naamlik die skool en gesin; en op mikrovlak - wat verwys na persoonlike invloed. Die volgende temas het tydens die triangulasieproses in sowel die kwalitatiewe asook kwantitatiewe resultate gemanifesteer: geslag; studiegewoontes; rol van emosies; die verband tussen probleemoplossing, dissipline en klaskamerbeheer; en die rol van stres en wiskundeangs in die middel-adolessent se wiskundeprestasie.

The mid-adolescent's achievement in maths: The role of emotional intelligence and study orientation. This study (quantitative-qualitative) focused especially on the extent to which (a combination of facets of) emotional intelligence (EI) and study orientation predict(s) the mathematics achievement of middle-adolescents, and also compared the performance of the different gender and grade groups (represented in this study). Altogether 435 learners in Grade 9 and Grade 11 from the three English medium high schools in the Mafikeng region took part in the study. The quantitative component of the study comprised the implementation of two standardised questionnaires: an EI questionnaire, the Bar-On EQ-i:YV ${ }^{\mathrm{TM}}$, and the study orientation questionnaire in mathematics (SOM). The qualitative technique implemented in the study was focus group interviews. The results indicated that a combination of the facets of emotional intelligence and the dimensions of study orientation could be considered potential predictors of the middle adolescent's mathematics achievement. The following EI components also emerged from the results as predictors of mathematics achievement: general mood, adaptability and intrapersonal behaviour. The following SOM dimensions were predictors of mathematics achievement: problem-solving behaviour, study habits, information processing and mathematics anxiety. Themes that emerged from the qualitative aspect of this study as potential contributors to learners' inadequate mathematics achievement refer specifically to challenges in South Africa at the macro level: mainly the input of the national government (and by default the Department of Education); on meso level: mainly factors related to the school and family; and on micro level: personality factors of the learner The following themes manifested in both the qualitative and quantitative results during the process of triangulation: gender, study habits, role of emotions, the relationship between problem-solving, discipline and classroom management; and the role of stress and maths anxiety in the maths achievement of the middle adolescent.

\section{Inleiding en probleemstelling}

Wiskundeprestasie is van kardinale belang vir enige ontwikkelende land. Navorsing het onder meer aangetoon dat wiskundeprestasie op skool een van die beste voorspellers van sukses 
op tersiêre vlak is en dat daar 'n statisties betekenisvolle verband bestaan tussen wiskundeprestasie en aspekte van studie-oriëntasie in wiskunde (insluitende studiegewoontes, wiskundeangs, houding jeens wiskunde, effektiewe tydsbestuur, ouerverwagting, asook leerders se sosiale en ervaringswêreld in wiskunde) (Maree 2009; Leppävirta 2011). Oor die afgelope 20 jaar fokus navorsers op, onder meer, die invloed van sosiale, kognitiewe en metakognitiewe, konatiewe en affektiewe fasette van prestasie in wiskunde (Van der Walt 2008; Pintrich 2002). Volgens Bar-On (2006) het gesaghebbende navorsing keer op keer bewys dat skoolprestasie, aanleg en intelligensie kwosiënt (IK) slegs sowat $9 \%$ van leerders se toekomstige sukses voorspel, terwyl emosionele intelligensie tussen $36 \%$ en $40 \%$ van hul toekomstige sukses voorspel. Die hoofdoel met die studie was om die verband tussen emosionele intelligensie en studieoriëntasie in wiskunde as moontlike voorspellers van die wiskundeprestasie van die middel-adolessent te bepaal.

\section{Konseptueel teoretiese raamwerk}

Die verband tussen emosionele intelligensie, studie-oriëntasie in wiskunde en die middel-adolessent se wiskundeprestasie is bestudeer teen die agtergrond van die sosiaalkonstruktivistiese benadering wat op sy beurt vanuit die interpretivistiese paradigma ontwikkel het, terwyl die komponent van emosionele intelligensie in die studie vanuit Bar-On se benadering tot EI geïnterpreteer is (Maree 2007). Deur die navorsing vanuit ' $n$ interpretivistiese paradigma te implementeer stel die navorser dit dat menslike gedrag net van 'binne' verstaan kan word. Die navorser fokus dus op hoe die persone hul ervarings tydens die leer van wiskunde 'konstrueer' deur betekenisgewinge met ander te deel. Volgens Niewenhuis (2007) is die uniekheid van die spesifieke situasie (konteks) belangrik om die betekenisse wat gekonstrueer word te verstaan en te interpreteer (Maree 2007). In hierdie studie is daar gevolglik op die leerders se subjektiewe ervarings van wiskunde gefokus. Hierdie subjektiewe ervarings tydens die leer van wiskunde sluit, onder meer, studie-oriëntasie in wiskunde en emosionele intelligensie in.

\section{Emosionele intelligensie}

Emosionele intelligensie is ' $\mathrm{n}$ niekognitiewe komponent van intelligensie en mense wat emosioneel en sosiaal intelligent is, beskik oor die vermoë om hulleself te verstaan en uit te druk, om ander se emosies te herken en te verstaan en om die eise van die daaglikse lewe suksesvol te hanteer (Bar-On, Maree \& Elias 2006). Die emosioneel intelligente individu beskik ook oor probleemoplossingsvaardighede, die vermoë om konstruktiewe verhoudings met ander in stand te hou en om selfmotiverend te wees. Emosionele intelligensie word in verband gebring met kinders se lewensen skoolgereedheid, akademiese sukses, asook volwassenes se werksukses en huweliksverhoudings (Bharwaney 2007; Cilliers 2004; Louw \& Louw 2007). Die eerste kernaspekte van emosionele intelligensie verwys onder meer na Algemene gemoedstoestand wat ' $n$ aanduiding gee van die individu se vlak van optimisme, gevoelens en geluk. 'n Volgende kernaspek verwys spesifiek na Aanpasbaarheid wat 'n aanduiding gee van die individu se realiteitstoetsing, buigsaamheid, asook probleemoplossingsvaardighede. Intrapersoonlike vaardighede verwys na die beheer van eie emosies, selfgelding, selfrespek, selfaktualisering en onafhanklikheid, waarteenoor Interpersoonlike vaardighede verwys na empatie, sosiale en maatskaplike verantwoordelikhede en interpersoonlike verhouding. Die laaste kernaspek van emosionele intelligensie is Stresbestuur wat na die individu se strestoleransie en impulsbeheer verwys.

\section{Emosionele intelligensie, akademiese prestasie en geslag}

Navorsing dui daarop dat daar 'n verband tussen emosionele intelligensie en geslag is (Alumran \& Punamäki 2008; BarOn 2010; Jordan, McRorie \& Ewing 2010; Hogan et al. 2010). Volgens Bar-On (2007) is vroue meer van hul eie emosies bewus, terwyl mans meer bedrewe is om emosies te bestuur.

\section{Wiskundeprestasie vanuit die perspektief van emosionele intelligensie}

Douglas, Burton en Reese-Durham (2008) het bevind dat die wiskundeprestasies van leerders wat aan meervoudigeintelligensie-onderrigtegnieke (wat emosionele intelligensie insluit) blootgestel is, beduidend beter was as leerders wat slegs aan tradisionele onderrigtegnieke blootgestel is.

\section{Adolessent}

Louw en Louw (2007) definieer adolessensie as die oorgangstydperk tussen die kinderjare en volwassenheid. Soos met die ander ontwikkelingstadia wat adolessensie vooraf gaan, gebruik sielkundiges die volgende tydperke om adolessensie te beskryf: vroeë, middel- en laat adolessensie (Sadock \& Sadock 2003). Vir die doel van hierdie studie is daar spesifiek gefokus op die middel-adolessent $( \pm 15-17$ jaar $)$.

\section{Studie-oriëntasie in wiskunde}

Volgens Maree et al. (2005) hou studie-oriëntasie in wiskunde en die aanleer van die inhoud van wiskundige leerareas met mekaar verband. Verskeie navorsingstudies (Maree 1997; Maree, Prinsloo \& Claassen 1997; Van der Walt 2008) onderskryf die siening dat affek besluitneming en prestasie beïnvloed en dui daarop dat positiewe houdings en oortuigings in verhoogde insette en deursettingsvermoë neerslag vind (Damasio 1994; Goleman 1995). Maree, Prinsloo en Claassen (1997) meen dat leerders swak presteer in wiskunde omdat daar so min aandag aan hul studie-oriëntasie gegee word. Maree (1997) definieer studie-oriëntasie as 'n begrip wat, onder meer, houding teenoor studie, wiskundeangs, studiegewoontes en probleemoplossingsgedrag insluit.

\section{Studiehouding}

Griffin (2008) het bevind dat leerders se houding jeens wiskunde 'n beduidende voorspeller van wiskundeprestasie is. Townsend en Witton (2003) beklemtoon dat die negatiewe houding van leerders teenoor wiskunde wel positief beïnvloed kan word. 


\section{Wiskundeangs}

Rubinstein en Tannock (2010) omskryf die angs vir wiskunde as 'a negative affective response to mathematics' ['n negatiewe affektiewe reaksie op wiskunde]. Verskeie studies het ten doel om die moontlike oorsaak en gevolge van wiskundeangs te ondersoek. Sharma (1979) identifiseer 'n gebrek aan wiskundewoordeskat as 'n moontlike oorsaak van wiskundeangs. Die navorsingsbevindings van Chinn (2009) wys daarop dat sekere onderwerpe in die wiskundekurrikulum, soos langdeling, tot gelyke vlakke van angstigheid lei vir leerders in al die jaargroepe in die sekondêre skool. Die oorsake van hierdie angs kan volgens Leppävirta (2011) toegeskryf word aan drie moontlike faktore: dispositional [disposisionele] (sielkundige en emosionele aspekte soos houding jeens wiskunde, selfkonsep en leerstyle), situational [situasie] (verwys na aspekte wat te doen het met die inhoud van die wiskundekursus, die tempo van onderrig, terugvoering of gebrek aan terugvoering), en environmental [omgewing] (ouderdom, geslag, vorige wiskundeondervindinge).

\section{Studiegewoontes in wiskunde}

Mayer (1994) definieer studiegewoontes en strategieë as die aktiwiteite wat die leerder gedurende die leerproses uitvoer met die doel om leer te bevorder. Volgens Reynolds (2006) kan studiegewoontes in drie komponente verdeel word: die gedrag wat leerders teenoor leer beoefen, die gedrag wat tydens die proses van leer plaasvind en gedrag wat bedoel is as hulpbronne wat die proses van leer bevorder. Studiegewoontes sluit, volgens Maree (1997), ook tydsbestuur, die vermoë om gefokus te bly en die toepassing van verworwe doeltreffende studiemetodes in.

\section{Probleemoplossingsgedrag}

Probleemoplossingsgedrag word deur Maree (1997) verduidelik as kognitiewe en metakognitiewe gedrag wat deur leerders geïmplementeer word en sluit onder meer strategieë soos voorspelling, beplanning, selfmonitering en selfevaluering in. Schoenfeld, in Van der Walt (2008), toon aan dat probleemoplossingsgedrag nie as suiwer kognitief van aard beskou kan word nie, aangesien leerders opinies oor die waarde van wiskunde het. Sulke oortuigings beïnvloed weer die kognitiewe gedrag wat tydens die leerproses geïmplementeer word.

\section{Studiemilieu in wiskunde}

Volgens Maree (1997) kan 'n swak studiemilieu gedefinieer word as 'n omgewing wat nie stimulerend vir die leerders is nie. Die leerder se fisieke welstand (fisieke milieu) oefen ook 'n invloed uit op sy of haar wiskundeprestasie. Fisieke probleme soos 'n onvermoë om goed te sien of hoor, asook lees- en taalprobleme is beperkend en ondermyn prestasie in wiskunde. Voorts beïnvloed die atmosfeer (beleefde milieu) in die klaskamer ook die leerders se skolastiese prestasie en emosionele lewe (Goliath 1992). Klaskamerklimaateienskappe soos studieoriëntasie en die mate waarin leerders as 'n groep die onderrig van wiskunde as 'n konstruktivistiese ervaring beleef, blyk volgens Van Damme, Opdenakker en Van den Broeck (2004) relevant te wees vir leerders se houding teenoor wiskunde.

\section{Inligtingverwerking}

Volgens Woolfolk (1990) neem die menslike brein inligting in en verrig dit sekere funksies om die inhoud te verander en te verwerk, sodat die persoon die inligting kan verstaan. Hierna word die inligting gestoor sodat dit weer gebruik kan word wanneer die persoon dit nodig het. Volgens die mees algemene inligtingverwerkingsteorieë word alle menslike kennis gestruktureerd en georganiseerd geberg (Gathercole \& Alloway 2008).

\section{Doel met ondersoek}

Die hoofdoel van hierdie studie is om ondersoek in te stel na die verband tussen komponente van emosionele intelligensie en die dimensies van studie-oriëntasie in wiskunde as moontlike voorspellers van middel-adolessent se wiskundeprestasie.

Die studie het ten doel gehad om die volgende twee vrae te beantwoord:

- Tot watter mate voorspel 'n kombinasie van komponente van emosionele intelligensie en dimensies van studieoriëntasie middel-adolessente se wiskundeprestasie?

- Hoe sien die vergelyking tussen die kwalitatiewe en kwantitatiewe resultate ten opsigte van die onderskeie geslag- en graadgroepe daar uit?

Hierdie twee vrae het spesifiek gefokus op die verband tussen:

- Die vyf komponente van die BarOn EQ-i:YV ${ }^{\mathrm{TM}}$ (1) intrapersoonlike vaardighede; (2) interpersoonlike vaardighede; (3) stresbestuur; (4) aanpasbaarheid en (5) algemene gemoedstoestand

- Dimensies van die SOW: (1) studiehouding; (2) wiskundeangs; (3) studiegewoontes; (4) probleemoplossingsgedrag; (5) studiemilieu en (6) inligtingverwerking.

- Die persentasiepunt wat die adolessent aan die einde van die jaar (2009) in wiskunde-assessering behaal het. Die vraelyste is in 2010 geïmplementeer.

\section{Navorsingsmetode en -ontwerp}

\section{Beplanning en trek van die steekproewe}

In hierdie studie is daar van kwotasteekproefneming gebruik gemaak. Altesaam 435 leerders in graad 9 en graad 11 wat aan een van die drie Engels-medium hoërskole in die Molopogebied in Mafikeng verbonde is, het aan die steekproef deelgeneem en die twee meetinstrumente voltooi. Engels moes die onderrigtaal by al drie die skole wees, maar leerders kon enige van die ander 10 amptelike tale as moedertaal hê. Deelnemers is nie eksklusief uit ' $n$ bepaalde bevolkingsgroep geneem nie en het wit sowel as swart leerders ingesluit, en geen geslagsvoorkeur is as insluitingsvoorwaarde aangedui nie. Laastens was die skoolstatus onbelangrik, omrede twee skole openbare skole en die derde skool 'n privaat skool is. 
Leerders wat, nadat die twee meetinstrumente voltooi is, aan die fokusgroeponderhoud by elk van die drie deelnemende skole deelgeneem het, is deur hul skoolhoofde aan die hand van die volgende kriteria geselekteer: hulle moes aan die navorsingsprojek deelgeneem het en daar moes 'n eweredige verspreiding ten opsigte van geslag, kultuurgroep, graad- en wiskundeprestasie wees.

\section{Data-insameling}

Beide kwantitatiewe en kwalitatiewe data-insamelingstegnieke is in hierdie studie geïmplementeer ten einde ondersoek in te stel na watter komponente van emosionele intelligensie en dimensies van studie-oriëntasie in wiskunde moontlik 'n rol kan speel in die middel-adolessent se wiskundeprestasie. Die twee meetinstrumente is eerste voltooi, gevolg deur die fokusgroeponderhoude met geselekteerde leerders.

\section{Meetinstrumente}

Deelnemers het die BarOn EQ-i:YV ${ }^{\mathrm{TM}}$-vraelys (Bar-On \& Parker 2000a) en die SOW-vraelys (Maree 1997) voltooi wat gestandaardiseerde meetinstrumente is en as geldig en betroubaar beskou kan word.

\section{Kwantitatiewe aspek van die studie The Emotional Quotient Inventory: Youth Version (EQ-i: YV)(Bar-On \& Parker 2000b)}

Emosionele intelligensie bestaan volgens Bar-On (2009) uit vyf komponente: (1) intrapersoonlike vaardighede; (2) interpersoonlike vaardighede; (3) stresbestuur; (4) aanpasbaarheid en (5) algemene gemoedstoestand. Die betroubaarhede vir die BarOn EQ-i:YV ${ }^{\mathrm{TM}}$ (Noord-Amerikaanse steekproef, $N=9172$ ) was soos volg: vir die seunsgroep varieer die betroubaarheidskoëffisiënte (Cronbach se alfa- waardes) van 0.67 tot 0.90 in verskillende ouderdomsgroepe en vir die meisiesgroep varieer die betroubaarheidskoëffisiënt van 0.65 tot 0.90 in die verskillende ouderdomsgroepe. Die voordele van die Bar-On (EQ-i) lê volgens Bharwaney (2007) in die feit dat dit deur standvastige en uitgebreide navorsing onderlê word, meer as enige ander meetinstrument vir emosionele intelligensie wat tans beskikbaar is. Die uitgebreide navorsing het ' $n$ indrukwekkende stel norme geskep wat die geldigheid en betroubaarheid van die Bar-On (EQ-i) verseker. Die EQ-i:YV is nog nie vir 'n verteenwoordigende Suid-Afrikaanse normgroep gestandaardiseer nie, en daarom word die leser versoek om die uitslae (soos altyd in gevalle soos dié) met omsigtigheid te hanteer.

\section{Vraelys oor studie-oriëntering in wiskunde (SOW) (Maree 1997)}

Maree (1997) definieer studie-oriëntasie as 'n begrip wat, ondermeer, die volgende dimensies insluit: studiehouding, wiskundeangs, studiegewoontes, probleemoplossingsgedrag, studiemilieu en inligtingverwerking. Die studie-oriëntering in die wiskunde-vraelys bestaan uit ses subtoetse wat 92 stellings bevat, en wat verband hou met die individu se gevoelens en aksies rakende aspekte van sy of haar wiskundeprestasie. Die betroubaarheid vir die SOW $(N=2055)$ is soos volg: vir die verskillende subtoetse wissel Cronbach se alfa-betroubaarheidskoëffisiënte van 0.70 tot 0.80 en vir die vraelys as 'n geheel varieer die betroubaarheidskoëffisiënte van 0.89 tot 0.95 .

\section{Kwalitatiewe aspek van die studie Fokusgroeponderhoude}

Kwalitatiewe data is ingesamel deurdat daar een fokusgroeponderhoud by elk van die drie deelnemende skole gevoer is om die deelnemers se menings en opinies rakende wiskunde en wiskundeprestasie te hoor. Die fokusgroeponderhoude is binne 'n tydperk van twee weke in die namiddag by die skole afgeneem. Die leerders wat aan die fokusgroeponderhoude deelgeneem het, is deur die hoofde aan die hand van die volgende kriteria geselekteer: die leerders moes aan die navorsingsprojek deelgeneem het en dus ' $n$ toestemmingsbrief van hul ouers of voogde ingedien het; daar moes sover moontlik ewe veel seuns en meisies wees; daar moes 'n eweredige verspreiding van leerders in graad 9 en graad 11 wees en die leerders se wiskundeprestasie moes eweredig versprei wees tussen bogemiddelde, gemiddelde en ondergemiddelde wiskudeprestasie. By die skole waar daar verskeie kultuurgroepe was, is daar gepoog om leerders van verskeie kultuurgroepe in te sluit.

\section{Resultate Wiskundeprestasie}

'n Vergelyking van die gemiddelde persentasie in wiskunde soos behaal in die eindeksamen (2009) dui daarop dat die graad 9-groep 'n gemiddelde van $54.34 \%$ behaal het, terwyl die graad 11-groep $44.38 \%$ behaal het. Die graad 9-meisies se gemiddelde is $56.98 \%$, teenoor die graad 9-seuns se gemiddeld van $50.61 \%$. Die graad 11-meisies se gemiddelde is $44.03 \%$, en $44.89 \%$ vir die graad 11 -seuns. Die graad 9-groep se gemiddelde is hoër as dié van die graad 11-groep. Die graad 9-meisies se gemiddeld is hoër as die gemiddeld van die graad 9-seuns, maar vir die graad 11-groep is daar geen noemenswaardige verskil tussen die gemiddeldes van die wiskundepunt vir die twee geslagte nie.

\section{Kwantitatiewe data}

\section{Statistiese data-analise}

Korrelasies tussen EI-komponente, SOW-dimensies en wiskundeprestasie: Pearson se korrelasie is uitgevoer om die korrelasies van die komponente van die BarOn EQ-i:YV ${ }^{\mathrm{TM}}$ en dimensies van die SOW te bepaal, asook vir die onderskeie graad- en geslagsgroepe (Tabel 1).

Die hoogste korrelasie tussen die EI-komponente, SOWdimensies en wiskundeprestasie vir die totale groep varieer tussen -0.06 en 0.832 . Die hoogste korrelasie vir die totale groep word aangedui tussen probleemoplossing en studiegewoontes $(r=0.823)$. Laasgenoemde korreleer ook hoog met houding $(r=0.810)$. Houding korreleer voorts ook hoog 


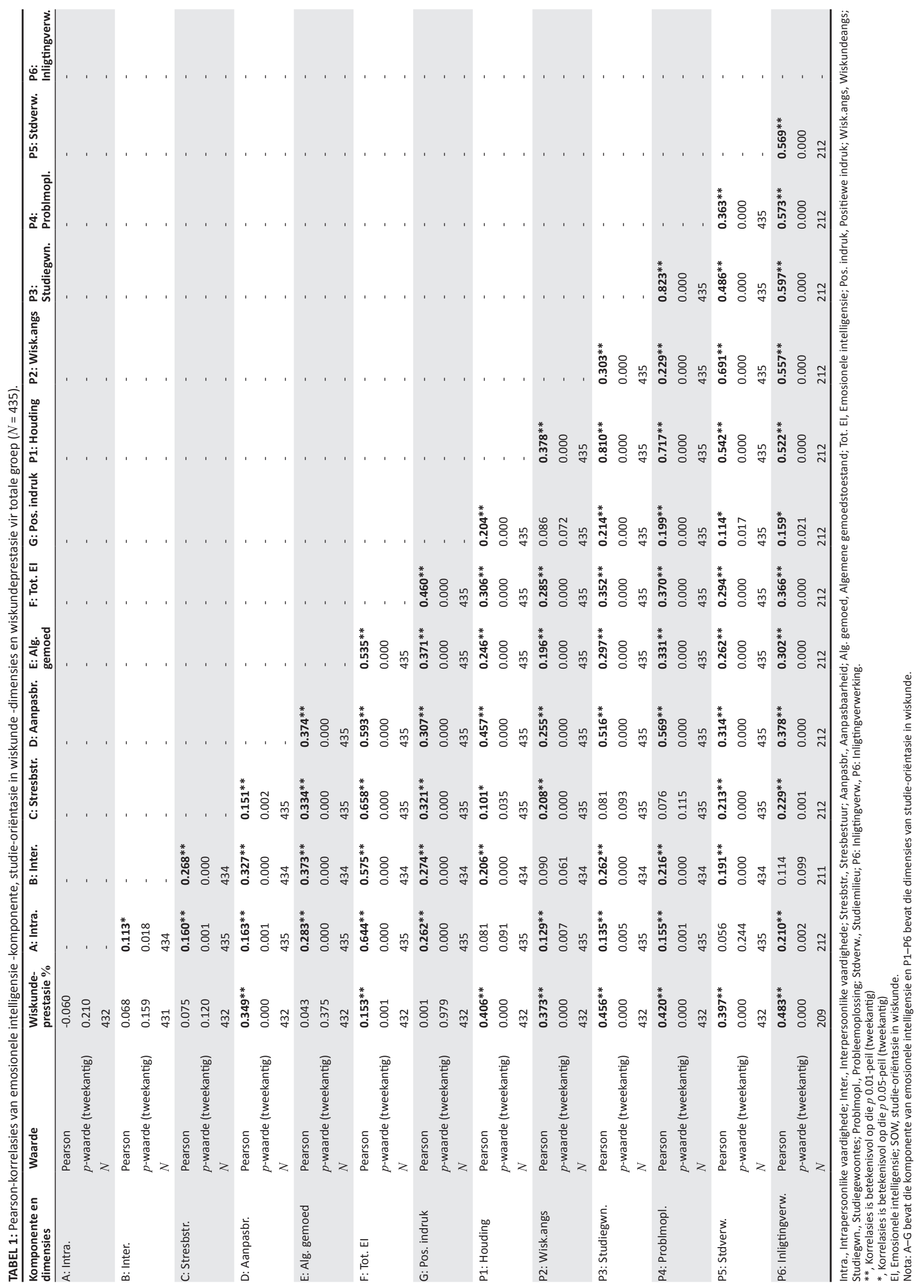


met probleemoplossing $(r=0.717(\mathrm{P} 4)$, studiemilieu $(r=$ $0.542)$ en inligtingverwerking $(r=0.522)$. Aanpasbaarheid (D) korreleer hoog met studiegewoontes $(r=0.516)$ en probleemoplossing $(r=0.569)$. Daar bestaan ook 'n hoë korrelasie tussen wiskundeangs, studiemilieu $(r=0.691)$ en inligtingverwerking (0.557). Hoë korrelasies bestaan ook tussen studiegewoontes (P3) en inligtingverwerking $(r=0.597)$. Inligtingverwerking korreleer hoog met al die dimensies van die SOW.

Regressie-analise: Stapsgewyse regressiemodelle is saamgestel om te bepaal in welke mate wiskundeprestasie voorspel kan word deur EI-velde en die SOW-dimensies. Die finale regressiemodel wat stapsgewyse in hierdie studie gebruik is, verklaar wiskundeprestasie van die graad 9-groep beduidend $(F=27.384 ; p<0.001)$ en al die voorspellers blyk hoogs betekenisvol te wees. Die bepaaldheidskoëffisiënt $\left(R^{2}\right)$ is 0.335 , wat beteken dat $33.5 \%$ van die variansie in die wiskundeprestasie van die totale graad 9-groep verklaar kan word deur studiegewoontes, wiskundeangs, algemene gemoedstoestand en aanpasbaarheid.

Die finale regressiemodel vir die graad 11-groep verklaar wiskundeprestasie beduidend $(F=21.125 ; p<0.001)$ en al die voorspellers blyk hoogs betekenisvol te wees. In hierdie geval is die bepaaldheidskoëffisiënt $\left(R^{2}\right) 0.294$, wat beteken dat $29.4 \%$ van die variansie in die wiskundeprestasie van die totale graad 11-groep verklaar kan word deur inligtingverwerking; probleemoplossing; intrapersoonlike vaardighede en aanpasbaarheid. In Tabel 2 word 'n samevatting van die voorspellers van wiskundeprestasie volgens graadgroepe (graad 9 en graad 11) aangedui.

\section{Kwalitatiewe data soos verkry uit fokusgroeponderhoude}

Temas, subtemas en kategorieë wat uit vorige literatuurstudies na vore getree het en wat na aanleiding van die dataontleding deduktief bevestig is, asook sub-subtemas wat op induktiewe wyse in hierdie studie na vore getree het, word in Tabel 3 aangedui.

Die volgende a priori-temas is tydens die literatuuroorsig geïdentifiseer: Tema 1 - studie-oriëntasie in wiskunde; Tema 1 - die rol van biografiese aspekte ten opsigte van wiskundeprestasie; Tema 3 - die invloed van ander rolspelers

TABEL 2: Vergelyking van voorspellers van wiskundeprestasie volgens graad (graad 9 en graad 11).

\begin{tabular}{llll}
\hline Graad & Beduidende voorspellers & $\begin{array}{l}\text { Regressie } \\
\text { koëffisiënte }\end{array}$ & $\begin{array}{l}\text { Gestandaardiseerde } \\
\text { koëffisiënte }\end{array}$ \\
\hline 9 & Studiegewoontes & 0.209 & $0.311^{* *}$ \\
& Wiskundeangs & 0.280 & $0.358^{* *}$ \\
& Algemene gemoedstoestand & -0.284 & $-0.213^{* *}$ \\
& Aanpasbaarheid & 0.239 & $0.167^{*}$ \\
11 & Inligtingverwerking & 0.227 & $0.372^{* *}$ \\
& Probleemoplossing & 0.086 & $0.148^{*}$ \\
& Intrapersoonlike vaardighede & -0.180 & $-0.167^{*}$ \\
& Aanpasbaarheid & 0.204 & $0.086^{*}$ \\
\hline
\end{tabular}

$* p<0.05$

$* * p<0.01$

$R^{2}=0.294$ op wiskundeprestasie; en Tema 4 - wiskundeprestasie binne die Suid-Afrikaanse konteks. Hierdie a priori-temas is op deduktiewe wyse aangewend as lense waardeur daar na die data gekyk is.

Temas wat uit die kwalitatiewe aspek van die studie na vore getree het as moontlik bydraend tot leerders se ontoereikende wiskundeprestasie in Suid-Afrika, verwys spesifiek na uitdagings op makrovlak, naamlik nasionale vlak wat terselfdertyd ook maatskaplike, sosiale en ekonomiese kontekste insluit op mesovlak, naamlik in die skool en gesin, en op die mikrovlak van persoonlike invloed.

\section{Wiskundeprestasie binne die Suid-Afrikaanse konteks Makrovlak ofte wel uitdagings op nasionale vlak}

Die opleiding van onderwysers in Suid-Afrika word deur een van die leerders bevraagteken. Twee leerders het ook verwys na probleme in die huidige politieke stelsel in SuidAfrika. Die invloed van korrupsie en waar korrupsie en onetiese gedrag (onder andere dat bevordering in die sakesektor nie op grond van jou kwalifikasies en ondervinding gemaak word nie, maar dat dit eerder gaan oor 'wie jy ken') aan die orde van die dag is. ' $n$ Gebrek aan positiewe rolmodelle wat die belangrikheid van wiskundeprestasie vir die jeug se toekomstige beroepslewe beklemtoon, is ook deur die leerders verwoord. Die leerders was ook van mening dat die gebrek aan 'n positiewe werksetiek onder die Suid-Afrikaanse bevolking bydra tot ontoereikende wiskundeprestasie en daarmee saam 'n negatiewe impak het op leerders se toekomstige beroepsmoontlikhede.

\section{Mesovlak: Skool en gesin}

Die leerders was ook van mening dat hul ouers ' $n$ belangrike rol speel deurdat hulle meer betrokke moet wees by die leerders se huiswerk en dat ouers die leerders moet motiveer om beter te presteer. Leerders wie se ouers die belangrikheid van wiskunde as vak beklemtoon het, het beter gepresteer in wiskunde. Die rol van die onderwysers as motiveerders is beklemtoon, maar die negatiewe impak op leerders se wiskundeprestasie indien onderwysers nie regtig toegewyd is nie, hulle te vinnig deur nuwe konsepte werk en nie seker maak dat alle leerders die konsepte bemeester het nie, het ook as subtema na vore getree. Die belangrikheid van die onderwyser se emosionele beheer het weliswaar as kategorie na vore getree. Die portuurgroep kan 'n motiverende invloed hê, maar leerders het ook laat blyk dat die lede van jou groep versigtig gekies moet word omrede dit ook 'n negatiewe impak om wiskundeprestasie kan hê. Leerders wat bogemiddeld presteer, het ook positiewe emosies ervaar wanneer hulle medeleerders met wiskunde kon help.

\section{Mikrovlak: Faktore binne die leerder self}

Die rol van studie-oriëntasie het sterk na vore getree deurdat gevoelens jeens wiskunde, selfvertroue, stres en vaardighede om stres te hanteer, asook studiemetodes, as 
TABEL 3: Opsomming van die temas, subtemas, kategorieë en subkategorieë wat op induktiewe en deduktiewe wyse uit die fokusgroepe na vore getree het.

\begin{tabular}{|c|c|c|}
\hline Tema & Subtema & Opsomming \\
\hline \multirow[t]{4}{*}{ Studie-oriëntasie in wiskunde } & Gevoelens jeens wiskunde & $\begin{array}{l}\text { - Liefde vir wiskunde } \\
\text { - Wiskunde is harde werk } \\
\text { - Nees vir wiskunde } \\
\text { Negatiewe ingesteldheid jeens wiskunde }\end{array}$ \\
\hline & Selfvertroue & - Oormaat selfvertroue \\
\hline & $\begin{array}{l}\text { Stres en streshanterings- } \\
\text { vaardighede }\end{array}$ & $\begin{array}{l}\text { - Stres as motiverende faktor } \\
\text { - Stres as verlammende faktor } \\
\text { - Onderwerpe in wiskunde veroorsaak meer stres as ander } \\
\text { Gedragsmanifestasie van stres: } \\
\text { - Eksternaliserende gedrag (bv. aggressie) } \\
\text { Internaliserende gedrag (bv. slaap) }\end{array}$ \\
\hline & Studiemetodes & $\begin{array}{l}\text { - Die waarde van groepwerk } \\
\text { - Die waarde van verduideliking deur emosioneel onderskragende vriende } \\
\text { - Die geduld van vriende wanneer hulle verduidelik } \\
\text { - Die kalmerende rol van musiek }\end{array}$ \\
\hline \multirow[t]{3}{*}{$\begin{array}{l}\text { Die rol van biografiese } \\
\text { aspekte ten opsigte van } \\
\text { wiskundeprestasie }\end{array}$} & $\begin{array}{l}\text { Geslag as faktor wat } \\
\text { wiskundeprestasie medebepaal }\end{array}$ & $\begin{array}{l}\text { - Meisies vaar beter as seuns in wiskunde } \\
\text { - Beide geslagte beskik oor dieselfde vermoëns om in wiskunde te presteer } \\
\text { wiskunder en werkingesteldheid word verkeerdelik vertolk as geslagsverwante faktor wat } \\
\text { wiskedebepaal }\end{array}$ \\
\hline & $\begin{array}{l}\text { Kulturele groep as faktor wat } \\
\text { wiskundeprestasie medebepaal }\end{array}$ & $\begin{array}{l}\text { - Leerders van Asiatiese herkoms presteer beter in wiskunde as leerders uit ander bevolkingsgroepe: } \\
\text { - Werksetiek van die Asiatiese leerders } \\
\text { - Ouderdom waarop Asiatiese leerders wiskunde begin leer } \\
\text { - Dit is slegs 'n stereotipering dat een kultuurgroep beter is as 'n ander kultuurgroep }\end{array}$ \\
\hline & $\begin{array}{l}\text { Onderrigtaal as faktor wat } \\
\text { wiskundeprestasie medebepaal }\end{array}$ & $\begin{array}{l}\text { - Gebrekkige waarde van Engels as onderrigtaal in wiskunde } \\
\text { - Waarde van Engels as internasionale onderrigtaal in die algemeen } \\
\text { - Afrikatale is problematies ten opsigte van die onderrig en leer van wiskunde }\end{array}$ \\
\hline \multirow[t]{3}{*}{$\begin{array}{l}\text { Invloed van ander rolspelers } \\
\text { op wiskundeprestasie }\end{array}$} & Rol van die ouers & $\begin{array}{l}\text { - Positiewe houding jeens wiskunde } \\
\text { - Ouers se siening van die belangrikheid van wiskunde as vak } \\
\text { - Ouers motiveer leerders om beter te presteer } \\
\text { - Oerband tussen die rol van die ouer en wiskundeprestasie } \\
\text { - Ouers moet meer betrokke wees by die leerders se huiswerk } \\
\text { Odolessensie as ontwikkelingstadium verstaan }\end{array}$ \\
\hline & Rol van die onderwysers & $\begin{array}{l}\text { - Onderwysers as motiveerders } \\
\text { - Negatiewe ervarings van leerders met nie-ondersteunende wiskunde-onderwysers in die hoërskool: } \\
\text { Onderwyser is nie regtig toegewyd nie } \\
\text { Onderwyser se gebrek aan emosionele beheer } \\
\text { - Onderwyser sukkel met klaskamerbeer }\end{array}$ \\
\hline & Rol van die groep & $\begin{array}{l}\text { - Groep as motiverende invloed: } \\
\text { Onderskragende rol van die groep } \\
\text { - Legatiewe invloed van die groep } \\
\text { - Die belangrikheid daarvan om die ander lid/lede van jou groep versigtig te kies }\end{array}$ \\
\hline \multirow[t]{2}{*}{$\begin{array}{l}\text { Wiskundeprestasie binne die } \\
\text { Suid-Afrikaanse konteks }\end{array}$} & $\begin{array}{l}\text { Moontlike redes vir } \\
\text { ontoereikende wiskundeprestasie }\end{array}$ & $\begin{array}{l}\text { - Nasionale vlak - Probleme in die huidige politieke stelsel: } \\
\text { - Die invloed van korrupsie } \\
\text { - Bevordering word bepaal deur wie 'n mens ken } \\
\text { - Belangrikheid van onderrig as die sleutel tot beter geleenthede word nie meer beklemtoon nie: } \\
\text { - Maatskaplike vlak: } \\
\text { - Gebrek aan 'n positiewe werksetiek by die Suid-Afrikaanse bevolking } \\
\text { - Opleiding van onderwysers } \\
\text { - Suid-Afrikaanse leerders se ontoereikende werksingesteldheid in die algemeen } \\
\text { - Tydsbestuur van individuele leerders. } \\
\text { - Tydsbestuur van die leerders tydens die skryf van formele assesserings } \\
\text { - Leerders is nie leergierig nie } \\
\text { - Die gebrek aan motivering en omgee deur die onderwysers } \\
\text { - Ontoereikende klaskamerbeheer } \\
\text { - Navorsers kry nie altyd'n korrekte indruk van klaskamergebeure nie }\end{array}$ \\
\hline & $\begin{array}{l}\text { Voorstelle om ontoereikende } \\
\text { wiskundeprestasie te verbeter }\end{array}$ & $\begin{array}{l}\text { - Leerderverwante voorstelle } \\
\text { - Voorstelle wat verwys na die aanbieding van die vak } \\
\text { Skoolverwante voorstelle: } \\
\text { - Fokus op onderrig oor die hele skoolloopbaan heen in plaas van oordrewe fokus op graad } 12 \text { alleen } \\
\text { - Onderwyserverwante voorstelle: } \\
\text { - Onderwysers moet meer geduld aan die dag lê } \\
\text { - Onderwysers moet passievol wees oor die vak }\end{array}$ \\
\hline
\end{tabular}

moontlike voorspellers van wiskundeprestasie as subtemas en subkategorieë gemanifesteer het.

Die leerders verwys ook na die Suid-Afrikaanse leerders se ontoereikende ingesteldheid in die algemeen teenoor werk, asook na die tydsbestuur van leerders ten einde 'n balans te kry tussen hul sosiale lewe en wiskundeprestasie. Die graad 11-leerders was van mening dat leerders gehelp moet word met tydsbestuur tydens die skryf van formele assesserings en meld dat leerders nie meer leergierig is nie en verder ook ' $n$ negatiewe houding jeens boeke het. Dit sluit aan by die uitspraak van Rademeyer (2009) dat die gebrekkige leerkultuur by skole ' $n$ bydraende faktor tot Suid-Afrikaanse leerders se swak prestasie in wiskunde is. Leerders was ook van mening dat navorsers nie altyd 'n korrekte indruk van klaskamergebeure kry nie en die voorstel is gemaak dat videokameras in die klaskamers gebruik kan word om die gedrag van leerlinge, asook gebeure in die wiskundeklaskamer te monitor, en dat dit as een moontlike data-insamelingsmetode oorweeg moet word. 


\section{Etiese oorwegings}

Skriftelike toestemming vir deelname is bekom van die Universiteit van Pretoria se etiekkomitee, Noordwes se Provinsiale Onderwysdepartement in Mafikeng, hoofde en beheerliggaamvoorsitters van die betrokke drie skole, asook van die ouers of voogde en van die graad 9- en graad 11-leerders self wat aan hierdie studie deelgeneem het; en hulle is ook skriftelik oor die navorsing en hul regte ingelig.

Die biografiese vraelys is eerste voltooi, gevolg deur die EQ-i:YV en die SOW. Die vrywillige deelname en die deelnemers se reg om in enige stadium van die studie te onttrek is beklemtoon en vertroulikheid is verseker deurdat alle name en identifiserende inligting met pseudonieme vervang is. Deelnemers is teen enige fisieke en/of geestelike ongemak en gevaar beskerm deurdat 'n geregistreerde kliniese sielkundige teenwoordig was tydens die afneem van die antwoorde op vraelyste, en die leerders kon enige tyd 'n afspraak maak sou hulle geestelike ongemak ervaar nadat die toetse afgeneem is. Skriftelike terugvoering in die vorm van 'n verslag wat die profiele van, asook beweegrede vir onderafdelings van die Bar-on EQ-i:YV (Bar-On \& Parker 2000b) en SOW (Maree 1997) verduidelik, is aan elke individuele leerder (en hul ouers) gegee.

\section{Bespreking \\ Triangulasieproses: Temas in beide die kwantitatiewe en kwalitatiewe resultate}

\section{Geslag as faktor wat die middel-adolessent se} wiskundeprestasie medebepaal

Die prestasies van graad 9-meisies (56.98\%) (soos gemeet deur hulle jaareindpunte in wiskunde in 2010) toon hoër gemiddelde punte in wiskunde as die graad 9-seuns (50.61\%). Daar was egter amper geen verskil in die wiskundegemiddeldes van die graad 11-seuns (44.89\%) en -meisies $(44.03 \%)$ nie. Sommige leerders was van mening dat meisies beter vaar in wiskunde as seuns, terwyl ander leerders geglo het dat wiskundeprestasie onafhanklik van geslag is. Nie een leerder het egter aangedui dat seuns beter as meisies in wiskunde presteer nie.

'n Positiewe bevinding van hierdie studie is dat dit blyk dat stereotipering ten opsigte van wiskundeprestasie in hierdie gemeenskap aan die afneem is. Die bevindings in dié betrokke studie dui daarop dat die graad 9-meisies se wiskundeprestasie (gemiddelde wiskundepunte) hoër is as dié van die seuns. Een moontlike verklaring hiervoor is dat die ma's in hierdie gemeenskap hul dogters meer motiveer om ekonomies onafhanklik te wees. Die navorser is die afgelope 20 jaar in private praktyk in die gemeenskap en moontlike redes vir die afname in stereotipering ten opsigte van wiskundeprestasie is dat die meisies meer blootstelling kry aan beroepsuitstallings by die universiteite en besoeke deur universiteite aan die skole. Een moontlike rede vir die graad 9-seuns se ontoereikende wiskundeprestasie kan wees dat hierdie betrokke gemeenskap nie genoeg gesonde vermaak vir die adolessent bied nie en dat vrye tyd meestal verwyl word deur by negatiewe bedrywighede betrokke te raak. Dit is dan ook tans in die oorgrote meerderheid gevalle die seuns in hierdie gemeenskap wat betrokke raak by hierdie bedrywighede. Dit hou hulle dikwels uit die skool of beïnvloed hul houding teenoor skoolwerk negatief, iets wat moontlik verband kan hou met hoër vlakke van impulsiwiteit (Davis \& Carr 2001).

\section{Studiegewoontes}

Studiegewoontes het as die tweede belangrikste voorspeller van wiskundeprestasie vir beide die graad 9- en graad 11-meisies na vore getree het. Hierdie bevinding kan moontlik in ' $n$ bepaalde mate spruit uit die feit dat onderwysers verbonde aan die skole wat deelgeneem het aan die studie oorwegend die mening toegedaan is dat harde werk in wiskunde (insluitend toereikende studiegewoontes) 'n vername rol speel in wiskundeprestasie en dat hierdie faset sterk beklemtoon en bevorder word in hul klasse.

\section{Rol van emosies}

Alhoewel baie studies verwys na die rol van affek in wiskundeprestasie, kon ek geen studie vind wat spesifiek verwys na die rol van emosies (soos gedefinieer in terme van emosionele intelligensie) in die middel-adolessent se wiskundeprestasie nie. Die volgende drie komponente van EI het as voorspellers van wiskundeprestasie na vore getree: aanpasbaarheid (vir beide graad 9 en graad 11), Intrapersoonlike vaardighede (vir graad 11) en algemene gemoedstoestand (vir graad 9). Die emosionele klimaat in die wiskundeklaskamer, en veral die onderwyser se gebruik en verstaan van emosies, is potensieel belangrik vir die leerders in die hoërskool, aangesien die algemene gemoedstoestand (soos gemeet deur die BarOn EQ-i:YV ${ }^{\mathrm{TM}}$ ) onder meer verwys na 'n positiewe ingesteldheid. Hierdie positiewe ingesteldheid moet deur die wiskundeonderwyser aan die leerders gemodelleer word. Die mening is ook uitgespreek dat die onderwyser se gebrek aan beheer in die klaskamer wat ook die onderwyser of onderwyseres se algemene emosionele beheer insluit, bydra tot leerders se negatiewe ervarings van die wiskundeonderwyser, wat dan weer hul wiskundeprestasie negatief beïnvloed.

\section{Die verband tussen probleemoplossing (in wiskunde), dissipline en klaskamerbeheer}

Die verband tussen probleemoplossing (in wiskunde), dissipline, asook klaskamerbeheer en die middel-adolessent se wiskundeprestasie is in beide die kwan- en kwal-analise uitgewys. Dit sluit aan by die emosionele klimaat van die klaskamer wat een van die voorvereistes vir probleemoplossing is. Een van die moontlike redes waarom hierdie tema uitgewys is, is dat daar nie sprake van wiskundeleer kan wees as die onderwyser onderrigtyd moet gebruik om beheer in die klaskamer toe te pas nie (Tsanwani 2009). Dissipline en klaskamerbeheer hou ook verband met ontwrigtende gedrag in die wiskundeklas, wat veral bydra tot seuns se ontoereikende wiskundeprestasie (Kenney-Benson et al. 2006). 


\section{Rol van stres en wiskundeangs}

Die rol van stres en wiskundeangs het uit sowel die kwanen kwal-analise geblyk. Die graad 9-leerders het aangedui dat hulle stres as debiliterend ervaar, teenoor die graad 11-leerders wat dit as motiverend ervaar. Dit is bekend dat stres motiverend of remmend kan inwerk op 'n leerder se wiskundeprestasie (Mattarella-Micke et al. 2011). Die navorsingbevindings van hierdie studie verwys egter ook na die verskillende wyses waarop seuns en meisies stres hanteer. Daar is nie voorheen in die literatuur enige kwantitatiewe en kwalitatiewe studies wat verwys na gedragsmanifestasies van stres as gevolg van wiskunde nie en ook nie in terme van geslag nie. Dit blyk uit die bevindinge van hierdie studie dat die seuns in hierdie studie meer gebruik maak van eksternaliserende gedrag en die meisies van internaliserende gedrag om stres te hanteer. Die seuns raak aggressief (soos om goed te breek) en die meisies onttrek (deur te gaan slaap). Hierdie aggressiewe gedrag by die seuns kan moontlik toegeskryf word aan 'n gebrek aan emosionele woordeskat en swak streshanteringsvaardighede, wat indirek in verband gebring kan word met die seuns se emosionele intelligensie.

\section{Beperkinge van die studie}

$\mathrm{Al}$ drie die skole wat by die studie betrek is, gebruik Engels as onderrigtaal en is in die stedelike gebiede geleë en daarom kan die bevindings nie noodwendig as verteenwoordigend beskou word van skole in die landelike streke en waar moedertaalonderrig plaasvind nie. Slegs leerders wie se ouers skriftelike toestemming verleen het dat hul kinders wel aan die studie kon deelneem, is hierby betrek. Die feit dat die EQ-i:YV en die SOW in Engels afgeneem is, kon die deelnemers se prestasie negatief beïnvloed het, aangesien die oorgrote meerderheid van die deelnemers se moedertaal nie Engels is nie. Laastens kan die feit dat die EQ-i:YV vanuit 'n Westerse perspektief gestandaardiseer is ook die swart leerders se prestasie negatief beïnvloed het.

\section{Aanbevelings}

In die praktyk kan die wiskundekurrikulum aangepas word om groter voorsiening te maak vir die insluiting van programme om EI-vaardighede en studie-oriëntasie in wiskunde by leerders te ontwikkel. Die afneem van die SOW aan die begin van elke skooljaar kan aan die onderwysers waardevolle inligting gee rakende elke individuele leerder se studie-oriëntasie in wiskunde. Die toepassing van 'n EI-vraelys kan eweneens waardevolle inligting rakende die leerder se emosionele funksionering verskaf. Die inligting wat van die EI- en SOW-profiele verkry word, sal onderwysers in staat stel om die nodige sisteme in plek te stel om 'n stewige affektiewe onderbou te ontwikkel - iets wat 'n noodsaaklike ondersteunende struktuur vir toereikende kognitiewe prestasie in wiskunde is. Dit sal ook aan die individuele leerders ' $n$ aanduiding gee van areas waar hulle reeds effektief funksioneer en watter komponente van EI en dimensies van SOW verder by hulle ontwikkel moet word.
Navorsers kan in verdere navorsing let op die effek van die onderwyser se emosionele funksionering op die middeladolessent se wiskundeprestasie. Daar moet ook gekyk word of die implementering van 'n EI-program en studie-oriëntasie as deel van die wiskundekurrikulum ' $n$ beduidende verskil sal maak aan die middel-adolessent se wiskundeprestasie. Die verband tussen EI en onderwysers se klaskamerbeheer kan ook onder die vergrootglas kom om vas te stel of die onderwysers se beheer in die klaskamer sal verbeter as hulle beskik oor meer effektiewe vaardighede wat op emosionele intelligensie dui .

Beleidmakers moet op die vlak van onderwysersopleiding in die Suid-Afrikaanse konteks daarop fokus dat onderwysers met meer effektiewe vaardighede toegerus word om beheer in die klaskamer te handhaaf. So byvoorbeeld behoort EIprogramme deel uit te maak van onderwysers se voortgesette opleiding. Huidige beleid ten opsigte van leerlinggetal per onderwyser, asook klasgroottes moet dringend hersien word. Oorgroot klasse maak klaskamerbeheer baie moeilik wat dan bydra dat waardevolle onderrigtyd afgestaan word aan die skep van orde, en nie aan die oordra en verduideliking van nuwe konsepte nie.

Die moontlikheid om onderwysersassistente op te lei moet ook verder ondersoek word. Hierdie onderwysersassistente moet opgelei word om die onderwyser of onderwyseres te assisteer in die klaskamer. Die onderwysersassistente kan die leerders byvoorbeeld in kleiner groepies help met leerhindernisse en leeragterstande deur die konsepte weer te verduidelik.

\section{Samevatting}

Die bevindings van hierdie studie suggereer dat die toepassing van 'n vraelys oor emosionele intelligensie en studie-oriëntasie in wiskunde 'n nuttige doel in wiskundeklaskamers kan dien. Dit kan help om ontoereikende wiskundeprestasie by leerders te verken sodat daar strategieë beplan kan word wat die moontlike leemtes in leerders se emosionele intelligensieen studie-oriëntasieraamwerke kan hanteer.

In 'n studie deur Homel et al. (2012) is daar bevind dat kultuurverwante faktore (skoolverwante ervarings), deelname aan hoërisiko-aktiwiteite (die gebruik van sterk drank en rook), en leerders se aspirasies die belangrikste voorspellers is of graad 12 voltooi gaan word. Materiële faktore, soos gemeet deur gesinsinkomste, blyk 'n onbelangrike rol te speel. Insgelyks is bevind dat ouers se opvoedingspeil en beroepstatus nie die uiteindelike slaag of druip van graad 12-leerders betekenisvol beïnvloed nie.

Ten slotte die volgende aanhaling uit die verslag van Homel et al.: 'This suggests that the negative effect of student problem behaviour on Year 12 completion is weaker where better teachers are in place'. [In gevalle waar meer effektiewe onderwys by die leerders in hul finale jaar betrokke is, word probleemgedrag van leerders ook minder] (2012:33). Hierdie argument uit hul 
belangwekkende verslag bevestig die bevindings van dié studie. Daar is onteenseglik baie wat onderwysers kan doen om leerders in hul pogings te onderskraag om hul potensiaal te verwesenlik. Deur onder meer toepaslike stappe te doen om leerders se emosionele intelligensie en hul studieoriëntasie (wat motivering pertinent insluit) te verbeter, kan onderwysers volgens die outeur se mening betekenisvol daartoe bydra dat leerders nie slegs graad 12 suksesvol voltooi nie, maar moontlik ook voortgaan om hul potensiaal op 'n hoër vlak te verwesenlik.

\section{Erkenning}

Hierdie studie sou nie voltooi kon word sonder die finansiële hulp van die Noordwes-Universiteit nie. Die outeur wil hiermee haar opregte dank uitspreek teenoor haar studieleier Prof. Kobus Maree vir sy leiding met die navorsingsprojek en Dr Lizelle Fletcher vir die verwerking van die kwalitatiewe data.

\section{Mededingende belange}

Die outeur verklaar hiermee dat sy geen finansiële of persoonlike verbintenis het met enige party wat haar nadelig of voordelig kon beïnvloed het in die skryf van hierdie artikel nie.

\section{Literatuurverwysings}

Alumran, J.I. \& Punamaki, R., 2008, 'Relationship between gender, age, academic achievement, emotional intelligence, and coping styles in Bahraini adolescents', Individual Differences Research 6(2), 104-119.

Bar-On, R., 2000, 'Emotional and social intelligence: Insights from the Emotional Quotient Inventory (EQ-i)' in R. Bar-On \& J.D.A. Parker (eds.), Handbook of emotional intelligence, pp. 363-388, Jossey-Bass, San Francisco, CA.

Bar-On, R. \& Parker, D.A., 2000a, The handbook of emotional intelligence: Theory, development, assessment, and application at home, school, and in the workplace, Jossey-Bass, San Francisco, CA.

Bar-On, R. \& Parker, J.D.A., 2000b, BarOn EQ-i:YVTM BarOn Emotional Quotien Inventory: Youth Version. Technical Manual, Multi-Health Systems, Toronto, Canada.

Baro-On, R., 2006, 'The Bar-On model of emotional-social intelligence (ESI)', Psicothema $11,13-25$.

Bar-On, R., 2007, 'The impact of emotional intelligence on giftedness', Gifted Education International 22(1), 122-137. http://dx.doi.org/10.1177/026142940702300203

Bar-On, R., 2009, BarOn Emotional Quotient Inventory: Technical Manual, Multi-Health Systems, Toronto, Canada. PMCid:PMC2656952

Bar-On, R., Maree, K. \& Elias, M. (eds.), 2006, Educating people to be emotionally intelligent, Heinemann, Sandton. PMCid:PMC2198878

Bharwaney, G., 2007, Emotionally intelligent living (rev. edn.): Strategies for increasing your $E Q$, Crown House, London.

Boshoff, E., 2009, 'Die ontwikkeling van ' $n$ werksetiekvraelys gebaseer op ' $n$ holistiese filosofiese model van etiese besluitneming', PhD proefskrif, Universiteit van die Vrystaat.

Chinn, S., 2009, 'Mathematics anxiety in secondary students in England', Dyslexia: An International Journal of Research and Practice - Special Issue: Making links: Selected papers from the 7th Conference of the British Dyslexia Association 15(1), 61-68. http://dx.doi.org/10.1002/dys.381

Cilliers, J.A., 2004, 'Die standaardisering van ' $n$ emosionele intelligensiemeetinstrumen by kinders' PhD proefskrif, Universiteit van die Vrystaat. PMCid:PMC2291686

Damasio, A.R., 1994, Descartes error: Emotion, reason, and the human brain, G.P. Putnam Sons, New York.

Douglas, O., Burton, K.S. \& Reese-Durham, N., 2008, 'The effects of the multipe intelligence teaching strategy on the academic achievement of eigth-grade math students', Journal of Instructional Psychology 35(2), 182-187.

Gathercole, S.E. \& Alloway, T.P., 2008, Working memory and learning: A practical guide for teachers, Sage, Los Angeles.
Goleman, D., 1995, Emotional intelligence, Bantam, New York.

Goliath, G.G., 1992, Kollektiewe konflikgeoriënteerde gedrag en die studiegewoontes en -houdings van leerlinge', Ongepubliseerde Meestersverhandeling, Universiteit van Pretoria.

Griffin, J.G., 2008, 'Student attitudes and activities that influence student achievement', Dissertation Abstracts International Section A: Humanities and Social Sciences 68(8-A), 3335.

Hogan, M.J., Parker, J.D.A., Wiener, J., Watters, C., Wood, L.M. \& Oke, A., 2010, 'Academic success in adolescence: Relationships among verbal IQ, social support and emotional intelligence', Australian Journal of Psychology 61(1), 30-41. http:// dx.doi.org/10.1080/00049530903312881

Homel, J., Mavisakalyan, A., Nguen, H. T. \& Ryan, C., 2012, School completion: What we learn from different measures of family background, NCVER, Adelaide, Australia.

Jordan, J.A., McRorie, M. \& Ewing, C., 2010, 'Gender differences in the role of emotional intelligence during primary-secondary school transition', Emotional and Behavioural Difficulties 15(1), 37-47. http://dx.doi.org/10.1080/13632750903512415

Kenney-Benson, G.A., Pomerantz, E.M., Ryan, A.M. \& Patrick, H., 2006, 'Sex differences in math performance: The role of children's approach to schoolwork', Developmental Psychology 42(1), 11-26. http://dx.doi.org/10.1037/0012-1649. 42.1.11, PMid:16420115

Leppävirta, J., 2011, 'The impact of maths anxiety on the performance of students of electromagnetics', Journal of Engineering Education 100(3), 424-443. http:// dx.doi.org/10.1002/j.2168-9830.2011.tb00021.x

Louw, D. \& Louw, A., 2007, Die ontwikkeling van die kind en adolessent, Universiteit van die Vrystaat, Bloemfontein.

Louw, D. \& Louw, A., 2009, Adult development and ageing, University of the Free State, Bloemfontein.

Maree, J.G., 1997, 'Die ontwerp en evaluering van 'n studieoriëntasiesvraelys in wiskunde', PhD proefskrif, Universiteit van Pretoria.

Maree, J.G., 2007, First steps in research, Van Schaiks, Pretoria.

Maree, J.G., 2009, 'Die uitdaging van ontoereikende wiskundeprestasie: Fokus op 'n metabenadering', Suid-Afrikaanse Tydskrif vir Natuurwetenskap en Tegnologie 28(4) 265-287.

Maree, J.G., Molepo, J.M., Owen, J. H. \& Ehlers, R., 2005, "n Probleemgebaseerde benadering tot wiskunde in graad 9 en graad 11 in die Limpopo-provinsie', SuidAfrikaanse Tydskrif vir Natuurwetenskap en Tegnologie 24(4), 124-133.

Mattarella-Micke, A., Mateo, J.M., Kozak, M.N., Foster, K.T. \& Beilocks, L., 2011, 'Choke or thrive? The relationship between salivary cortisol and maths performance depends on individual differences in working memory and math anxiety', Emotion 11(4), 1000-1005. http://dx.doi.org/10.1037/a0023224, PMid:21707166

Maree, J.G., Prinsloo, W.B. \& Claassen, N.C., 1997, Handleiding vir die studieoriënteringsvraelys in Wiskunde (SOW), Raad vir Geesteswetenskaplike Navorsing, Pretoria. PMid:9152425

Mayer, R.E., 1994, 'Study habits and strategies', in Y. Husen \& T.N. Postlethwaite (eds.) The international encyclopedia of education, pp. 5829-5831, Pergamon, Great Britian.

Niewenhuis, J., 2007, 'Introducing qualitative research', in J.G. Maree (ed.), First steps in research, pp. 47-68, Van Schaik, Pretoria.

Pintrich, P. R., 2002, 'The role of metacognitive knowledge in learning, teaching and assessing', Theory into Practice 41(4), 219-225. http://dx.doi.org/10.1207/ s15430421tip4104_3

Rademeyer, A., 2009, 'Suid-Afrika se Wiskunde-krisis: Innoverende oplossing nou nodig' Suid-Afrikaanse Tydskrif vir Natuurwetenskap en Tegnologie 28(4), 393-397. http:// dx.doi.org/10.4102/satnt.v28i4.76

Reynolds, M., 2006, Die verband tussen studie-oriëntasie, metakognisie en wiskundeprestasie by graad 7-leerders, Ongepubliseerde Meestersverhandeling, NoordwesUniversiteit, Potchefstroom

Rubinstein, O. \& Tannock, R., 2010, 'Mathematics anxiety in children with developmental dyscalculia', Behavioral and Brain Functions 6, 46. http://dx.doi.org/10.1186/1744 9081-6-46, PMCID: PMC2913999

Sadock, B.J. \& Sadock, V.A., 2003, Synopsis of Pscyhiatry, 9th edn., Williams \& Wilkins, Philadelphia, PA.

Sharma, M.C., 1979, 'Focus on learning problems', Mathematics 1(3), 5-22.

Townsend, M. \& Witton, K., 2003, 'Evaluating change in attitude towards Mathematics using the "then-now" procedure in a cooperative learning programme', British Journal of Educational Psychology 73(4), 473-487. http://dx.doi.org/10.1348/ 000709903322591190, PMid:14713373

Van Damme, J., Opdenakker, M. \& Van den Broeck, A., 2004, 'Co classes and schools have an effect on attitudes towards mathematics?', viewed 16 Octbober 2013 from www.iea.nl/irc2004-timss.html

Van der Walt, M. S., 2008, 'Aanpassing van die studie-oriënteringsvraelys in Wiskunde vir die gebruik in die intermediêre fase', PhD proefskrif, Noordwes-Universiteit

Van der Walt, M. S., 2009, 'Studieoriëntasie en basiese woordeskat in wiskunde in die laerskool', Suid-Afrikaanse Tydskrif vir Natuurwetenskap en Tegnologie 24(4), 378-392

Woolfolk, A.E., 1990, Educational psychology, 4th edn., Prentice-Hall, Hillsdale. 